\begin{tabular}{ccc}
\hline International Journal of Engineering \& Technology, $7(4.26)(2018) 297-304$ \\
SPC \\
Website w ww. sciencepubco.com/index.php/IJET \\
Research paper
\end{tabular}

\title{
Stocks Allocation in Portfolio Selection using Fuzzy Soft Set
}

\author{
Shraddha Harode ${ }^{1}$, Manoj Jha ${ }^{2}$, Sujoy Das ${ }^{3}$, Namita Srivastava ${ }^{4}$ \\ ${ }^{1}$ Research scholar, Department of Mathematics \& Computer Applications, Maulana Azad National Institute of Technology Bhopal- \\ 462003 (M.P.) INDIA \\ ${ }^{2}$ Assistant Professor, Department of Mathematics \& Computer Applications, Maulana Azad National Institute of Technology Bhopal- \\ 462003 (M.P.) INDIA \\ ${ }^{3}$ Assistant Professor, Department of Mathematics \& Computer Applications, Maulana Azad National Institute of Technology Bhopal- \\ 462003 (M.P.) INDIA \\ ${ }^{4}$ Professor, Department of Mathematics \& Computer Applications, Maulana Azad National Institute of Technology Bhopal-462003
}

(M.P.) INDIA

\begin{abstract}
Return and risk are uncertain parameters for stock market. Fuzzy Soft Set is a suitable approach to handle the uncertaintiesvagueness and/or imprecisionof the market position and permits the data representation viably. The primary focus of paper is to construct the diversified portfolio of the stocks with the help of Fuzzy Soft Set (FSS) model.HereinFSS model is used for ranking the stocks viadecision making factor (DMF) and decision ranking factor (DRF).On the basis of this ranking7 stocks are picked up out of 30 stocks for construction of optimal portfolio. To solve optimization problem, Genetic Algorithm isused for stocks allocation of the optimal portfolio. The data set analysedin this model is taken from Bombay Stock Exchange (BSE) Mumbai, India and a real application are given in order to show the potentiality of the approach
\end{abstract}

Keywords: Portfolio Selection, Decision-Making Approach, Fuzzy number, Multi Objective Programming (MOP), Genetic Algorithm (GA), Soft Set.

\section{Introduction}

Hazard and return are two essential factors in monetary research. Money related hazard is the most critical and exhaustive piece of stock's execution. Speculators and monetary organization investigators balance the hazard return exchange off for their ventures. The distinctive approaches to expand cash between a few stocks is known as a portfolio. Portfolio hypothesis and related points are among the most tried regions of research in the monetary and money related research. Harry Markowitz distributed his spearheading work which is the establishment of present day portfolio investigation [30]. Markowitz introduced adjust display in which semi change as hazard measure to evaluate chance instead of fluctuation [31]. It is increasingly hard to taking care of extensive scale issue with a thick covariance network. Sharpe [38] introducedone distinctive very much enjoyed work in which the model that disentangled Markowitz's model by overlooking the covariance between returns. For the balance models, the Capital Stock Evaluating Models (CAPM) created which is less requesting Mean outright deviation show (Frantic). To defeat the challenges of MV model,Konno\& Yamazaki(Konno and Yamazaki, 1991)proposed another model utilizing mean outright deviation asrisk measure rather than standard deviation chance capacity. A huge size of portfolio determination issue can be effectively fathomed on account of it is direct model. Speranza [40] determined the hazard is by semi-total deviation show. The advancement issue diminished to a large portion of the quantity of requirements in contrast with the Konno's model. Simaan [39] inspected the minimization of Frantic model is near the MV show. The greater part of the issues, in financial aspects, sociology, condition and so on., have different vulnerabilities, in actuality, circumstance. One can't effectively utilize traditional courses as a result of different kinds of vulnerabilities for those issues. Jha and Srivatava [20] demonstrated a procedure that an arrangement of stocks is developed with the assistance of fluffy advancement strategy. A portion of these speculations are fluffy set [45], intuitionistic fluffy set [2], unpleasant set [35], ambiguous set [13], interim arithmetic and so forth. These hypotheses have their natural challenges as pointed out by Molodtsov [33]. It proposed the delicate set as a totally nonexclusive scientific device for demonstrating vulnerability. Scientists can pick the parameters as they require, which well characterizes the basic leadership process. It likewise makes the procedure progressively productive without incomplete data on the grounds that there is no constraining condition to the affirmation of articles. Delicate set hypothesis has demonstrated helpful in a wide range of fields, for example, therapeutic science $[7,36]$, information investigation [47], anticipating [42], reenactment [22], assessment [34], affiliation rule mining [18], and comparability measure $[32,44]$ and so forth. Delicate set is generally connected to basic leadership issue [32], in commonsense angles. Bellman \&Zadeh [4], displayed fluffy choice hypothesis. Maji et al presented some new meanings of a subset, a complementof delicate set and talked about the utilization of delicate set hypothesis in basic leadership issues [8, 27-29]. Fluffy Delicate Sets (FSS) are proposed for a similar basic leadership issues in numerous fields, in which last recognizable proof of the item depends on the arrangement of contributions from various financial specialists who give the complete article exhibit as far as a few arrangements of parameters by [28]. Fenget al. introduced a customizable way to deal with FSS based basic leadership. Fenget al. likewise characterized a delicate semi rings and some related thoughts to comprise an association between semi rings and delicate sets [11]. Aktasand Cagman [1], presented delicate gatherings and demon-

Copyright $\odot 2018$ Authors. This is an open access article distributed under the Creative Commons Attribution License, which permits unrestricted use, distribution, and reproduction in any medium, provided the original work is properly cited. 
strated that fluffy gatherings can be seen as an uncommon instance of the delicate gatherings. Zouand Xiao [47], characterized information examination approach for delicate set. Kong et al. [23], portrayed the delineating precedent in which the ideal choice isn't gotten by utilizing decision estimation of Roy and Maji's calculation [6]. selecteda set of ideal items byuni-int basic leadership strategies for delicate set and depicted the delicate frameworks [5], in which additionally presented a calculation for taking care of basic leadership issues utilizing with tasks of delicate networks. By joining the interim esteemed fluffy sets and delicate set models, Yang et al [21, 43]. Further presented interim esteemed fluffy delicate sets. Thakur (G. Thakur, 2014)proposed a model to anticipate the inadvertent spot utilizing FSS.In other existing technique, arrangement of portfolio is finished by picking arbitrary stocks as like Markowitz's model [30], GA [12], Reenacted Tempering [14] and so on parameter premise not on positioned. Be that as it may, FSS is deliberate, all around positioned.

Hereditary Calculation is stochastic improvement bolstered by the [19]. Laraschjand Tettamanzi [25], utilized the developmental calculation to define the portfolio streamlining issue with twoobjective.GA is best to other technique like PSO, SA [15] and GA is utilizing the arbitrary beginning populace for stocks allotment. Nowwith the assistance of FSS display, the positioned stocks will be utilized rather than irregular stocks in GA for portfolio improvement which results superior to utilizing arbitrary stocks.

In this paper, FSS display is proposed for development a portfolio ofstocks by DMF and DRF in which end point choice depends on the higherrank of the stocks by DRF table and DMF table. Here the ideal resources are built ideal portfolio which contains extent of the ideal stocks by Hereditary Calculation. Accordingly the base and greatest extent can be investedin any single stock.

The association of paper is as per the following: In Area 2 Delicate set is investigated. Segment 3 centers around Portfolio target terms for the stocks choice. In Segment 4, issue definition is introduced. Area 5 gives a portrayal of the basic leadership approach Segment 6 presents the Calculation. We have displayed the examination framework and its incited connections among DMF and

\begin{tabular}{|c|c|c|c|}
\hline \multirow{2}{*}{$\mathrm{F}\left(\mathrm{E}_{1}\right)=$} & $A_{1}$ & $A_{2}$ & $\mathrm{~A}_{3}$ \\
\hline & .0547 & $.1262^{\prime}$ & .0000 \\
\hline \multirow{2}{*}{$\mathrm{F}\left(\mathrm{E}_{2}\right)=$} & $A_{1}$ & $A_{2}$ & $\mathrm{~A}_{3}$ \\
\hline & .0127 & $.0000^{3}$ & .0029 \\
\hline \multirow{2}{*}{$\mathrm{F}\left(\mathrm{E}_{3}\right)=$} & $A_{1}$ & $A_{2}$ & $\mathrm{~A}_{3}$ \\
\hline & .0207 & $.0069^{3}$ & .0222 \\
\hline
\end{tabular}

\subsection{Definition}

Let $C_{i j}(i=0,1, \ldots, n: j=0,1, \ldots, m)$ be a fuzzy variable defined on the FSS $(\mathrm{F}, \mathrm{A})$, later its membership value is given by

$\mathrm{F}\left(\mathrm{C}_{\mathrm{ij}}\right)=\mathrm{C}_{\mathrm{ij}}+\lambda$

Where $\lambda \geq \max \{|x|,|y|, \ldots,|z|\}$ to negative value.

By and large the circumstance might be negative and decipher exactness as a number somewhere in the range of $0 \%$ and $100 \%$, consequently thoroughly we include $\lambda$, where $\lambda$ is any positive genuine number. Clearly, a proportion of how close is the genuine the gauge amount (Xiao et al., 2009). Moreover, we can speak to the fluffy delicate sets (F, An) as an unthinkable structure, see Table 7.

\section{Portfolio Objectives Terms for Stock Selec- tion}

\subsection{Expected Return}

DRF in Area 7. Furthermore, result and exchange are proposed in area 8. In area 9, displays some end from the outcome. Affirmation presents in Segment 10.

\section{Preliminaries}

\subsection{Definition}

Let $\mathrm{U}$ is a universe set and $\mathrm{E}$ is a set of parameters. Let $\mathrm{P}(\mathrm{U})$ denotes the power set of $\mathrm{U}$. Let $\mathrm{A} \subset \mathrm{E}$. A pair $(\mathrm{F}, \mathrm{A})$ is called a soft set over $\mathrm{U}$ by Molodtsov where $\mathrm{F}$ is a mapping given by $\mathrm{F}: \mathrm{A} \rightarrow$ $\mathrm{P}(\mathrm{U})[33]$.

Example: Let $U$ be the set of four stocks given by $U=\left\{d_{1}, d_{2}, d_{3}\right.$, $\left.\mathrm{d}_{4}\right\}$. Let $\mathrm{E}$ be the parameter set, given by $\mathrm{E}=\{$ Return, High Return, Low Return, Risk, High Risk, Low Risk, Liquidity, Medium Liquidity, Low Liquidity $\}$. Let $\mathrm{A} \subset \mathrm{E}$, given by, $\mathrm{A}=\{$ High Return, Return, Low Risk, Medium Liquidity $\}=\left\{\mathrm{e}_{1}, \mathrm{e}_{2}, \mathrm{e}_{3}, \mathrm{e}_{4}\right\}$. Now suppose that, $\mathrm{F}$ is a mapping given by, $\mathrm{F}\left(\mathrm{e}_{1}\right)=\left\{\mathrm{d}_{2}, \mathrm{~d}_{4}\right\}, \mathrm{F}\left(\mathrm{e}_{2}\right)$ $=\left\{d_{1}, d_{3}\right\}, F\left(e_{3}\right)=\left\{d_{2}, d_{3}\right\}, F\left(e_{4}\right)=\left\{d_{4}\right\}$. Then the Soft Set is $(F$, $\mathrm{A})=\left\{\mathrm{F}\left(\mathrm{e}_{1}\right), \mathrm{F}\left(\mathrm{e}_{2}\right), \mathrm{F}\left(\mathrm{e}_{3}\right), \mathrm{F}\left(\mathrm{e}_{4}\right)\right\}$.The tabular representation of soft set $(\mathrm{F}, \mathrm{A})$ is Table 1 .

\subsection{Definition}

Let $\mathrm{U}$ is auniversal set and $\mathrm{E}$ is a set of parameters. Let $\mathrm{P}(\mathrm{U})$ denotes the set of all fuzzy sets of U. Let A $\subset$ E. A pair $(F, A)$ is called FSS over U by Maji,et al [27], where $\mathrm{F}$ is a mapping given by,

$\mathrm{F}: \mathrm{A} \rightarrow \mathrm{P}(\mathrm{U})$

Example: Let universe $U=\left\{A_{1}, A_{2}, A_{3}, A_{4}, A_{5}, A_{6}, A_{7}\right\}$ be the seven selected stocks i.e. AMBUJACEM, ASHOKLEY, BANKINDIA, BRITANNIA, CIPLA, GAIL and HMVL. Let E = $\left\{E_{1}, E_{2}, E_{3}, E_{4}\right\}$ be the generic parameters where $E_{1}, E_{2}, E_{3}$ andE $E_{4}$ are return, risk, dividend and liquidity respectively in Table 2 . Let $\mathrm{A} \subset \mathrm{E}$ and $\mathrm{FSSis}(\mathrm{F}, \mathrm{A})=\left\{\mathrm{F}\left(\mathrm{E}_{1}\right), \mathrm{F}\left(\mathrm{E}_{2}\right), \mathrm{F}\left(\mathrm{E}_{3}\right)\right\}$ : Where $\mathrm{E}_{1}$ stands for return, $\mathrm{E}_{2}$ stands for risk and $\mathrm{E}_{3}$ stands for dividend.

$\begin{array}{llll}\frac{\mathrm{A}_{4}}{.1235}, & \frac{\mathrm{A}_{5}}{.0641}, & \frac{\mathrm{A}_{6}}{.0201}, & \left.\frac{\mathrm{A}_{7}}{.0852}\right\} \\ \frac{\mathrm{A}_{4}}{.0151}, & \frac{\mathrm{A}_{5}}{.0154}, & \frac{\mathrm{A}_{6}}{.0145}, & \left.\frac{\mathrm{A}_{7}}{.0030}\right\} \\ \frac{\mathrm{A}_{4}}{.0073}, & \frac{\mathrm{A}_{5}}{.0031}, & \frac{\mathrm{A}_{6}}{.0149}, & \left.\frac{\mathrm{A}_{7}}{.0058}\right\}\end{array}$

Let $R_{i}$ be a random variable showing the rate of return (per period) of the $\mathrm{i}^{\text {th }}$ stock. In particular, for the $\mathrm{i}^{\text {th }}$ stock the realization $r_{i t}$ of random the variable $R_{i}$ during period $\mathrm{t}(\mathrm{t}=1 ; 2, \ldots, \mathrm{T})$. The expected rate of return is given by

$\mathrm{r}_{\mathrm{i}}=\mathrm{E}\left[R_{i}\right]=\frac{\frac{1}{T} \sum_{\mathrm{i}}^{\mathrm{n}}}{r_{i t}}: \mathrm{i}=1,2, \ldots, \mathrm{n}$.

\subsection{Risk}

The semi-absolute deviation of return of portfolio $\left(x_{1}, x_{2}, \ldots, x_{n}\right)$ of the $\mathrm{i}^{\text {th }}$ stock $(\mathrm{i}=1,2, \ldots, \mathrm{n})$ during the period $\mathrm{t}, \mathrm{t}=1,2, \ldots, \mathrm{T}$ is expressed by

$$
\begin{aligned}
& w_{t}(x)=\quad\left|\min \left\{0, \sum_{i=1}^{n}\left(r_{i t}-r_{i}\right) x_{i}\right\}\right| \\
& =\frac{1}{T} \sum_{t=1}^{T} \frac{\left|\sum_{i=1}^{\mathrm{n}}\left(r_{\mathrm{it}}-r_{\mathrm{i}}\right)\right|+\sum_{\mathrm{i}=1}^{\mathrm{n}}\left(r_{\mathrm{i}}-r_{\mathrm{it}}\right)}{2} \\
& w(x)=\frac{1}{T} \sum_{t=1}^{T} w_{t}(x) \\
& \text { Here }{ }^{W(x)} \text { (Speranza, 1993) is used to measure the portfolio risk. }
\end{aligned}
$$




\subsection{Liquidity}

Liquidity is estimated the level of probability worried inside the change of speculation into money with none noteworthy misfortune in worth [10]. For the most part, speculators need greater liquidity, especially since in a positively trending business sector for stocks; returns on stocks with high liquidity will in general increment with time. Liquidity of benefits can't anticipate precisely by verifiable information on the grounds that the financial exchange is constantly dubious. To ponder this dynamic nature, the prospect of plausibility hypothesis esteems hugeness [17]. A trapezoidal fuzzy number $\tilde{L}=(l a, l b, \alpha, \beta)$ with tolerance interval $a$, $b$, left fuzziness $\alpha>0$ and right fuzziness $\beta>0$, denoted by turnover rate if its membership function retains the following form

$$
\mathrm{A}(\mathrm{t})=\left\{\begin{array}{lr}
1-\frac{a-t}{\alpha} & \text { if } a-\alpha \leq t \leq a, \\
1 & \text { if } a \leq t \leq b, \\
1-\frac{t-b}{\beta} & \text { if } a \leq t \leq b+\beta, \\
0 & \text { otherwise }
\end{array}\right.
$$

Using the fuzzy extension principle introduced by Zadeh [46] the crisp possilistic mean value of the turnover rate is given by

$$
L=\left(\frac{l a+l b}{2}+\frac{\beta-\alpha}{6}\right)
$$

\subsection{Dividend}

The expected annual dividend rate of $i^{\text {th }}$ stock is given as using the formula

$D_{i=T} \frac{1}{T} \sum_{t=1}^{T} d_{t}$

where $D_{i}$ the expected dividend rate of $i^{t h}$ stock and $d_{t}$ is the yearly dividend which is calculated by historical data.

\section{Problem Formulations}

The multi objective programming is formulated for portfolio selection problem

$$
\begin{aligned}
& \operatorname{Max} \sum_{i=1}^{n} r_{i} x_{i} \\
& \quad \sum_{t=1}^{T} \frac{\left|\sum_{i=1}^{n}\left(r_{i t}-r_{i}\right) x_{i}\right|+\sum_{i=1}^{n}\left(r_{i}-r_{i t}\right) x_{i}}{2 T} \\
& \operatorname{Max} \sum_{i=1}^{n} d_{i} x_{i} \\
& \quad \sum_{i=1}^{n}\left(\frac{L a_{i}+L b_{i}}{2}+\frac{\beta_{i}-\alpha_{i}}{6}\right) x_{i} \geq L, \\
& \sum_{i=1}^{n} x_{i}=1, \\
& l_{i} \leq x_{i} \leq u_{i}, \mathrm{i}=1,2, \ldots, \mathrm{n}, \\
& x_{i} \geq 0, \mathrm{i}=1,2, \ldots, \mathrm{n}, \\
& l_{i} \in\{0,1\}, \mathrm{i}=1,2, \ldots, \mathrm{n}, \\
& u_{i} \in\{0,1\}, \mathrm{i}=1,2, \ldots, \mathrm{n} .
\end{aligned}
$$

Where $\mathrm{L}$ is consistent which is given by financial specialist, speaks to the stocks. We change it into the accompanying structure to dispense with without a doubt the esteemed capacity in above conditions.

$$
\operatorname{Max} \sum_{i=1}^{n} r_{i} x_{i}
$$

$\operatorname{Min} \frac{1}{T} \sum_{t=1}^{T} P_{t}$

$\operatorname{Max} \sum_{i=1}^{n} d_{i} x_{i}$

S.t. $\sum_{i=1}^{n}\left(\frac{l a_{i}+l b_{i}}{2}+\frac{\beta_{i}-\alpha_{i}}{6}\right) x_{i} \geq L$,

$P_{t}+\sum_{i=1}^{n}\left(r_{i t}-r_{i}\right) x_{i} \geq 0, \mathrm{t}=1,2, \ldots, \mathrm{T}$,

$\sum_{i=1}^{n} x_{i=1}$,

$P_{t} \geq_{0, \mathrm{t}=1,2, \ldots, \mathrm{T}}$,

$l_{\tilde{i}} \leq x_{\tilde{i}} \leq u_{i, \mathrm{i}}=1,2, \ldots, \mathrm{n}$,

$x_{i} \geq_{0, \mathrm{i}=1,2, \ldots, \mathrm{n},}$

$l_{i} \in\{0,1\}, \mathrm{i}=1,2, \ldots, \mathrm{n}$,

$u_{i} \in\{0,1\}, i=1,2, \ldots, n$,

Here upper bound $\left(\mathrm{u}_{\mathrm{i}}\right)$ and lower bound $\left(\mathrm{l}_{\mathrm{i}}\right)$ are incorporated on the speculation to stay away from the substantial number of extremely little venture (lower bound) and in the meantime to safeguard an adequate expansion of speculation (upper bound). The upper bound and lower bound were picked mindfully with the goal that the doable arrangement will exist.

\section{Financial Fuzzy Soft Set Model Based on Fuzzy Soft Set Decision Theory}

The FSS model proposed in which decision making technique is done in two phases. The first phase of the decision process called DRF is performed by fuzzy soft set table. The second phase DMF is performed with the help of comparison table. These phases of the decision process aims at understanding and defining values that will be used to select the optimal stocks.

\subsection{Comparison matrix}

Comparison table in which the number of rows and number of columns are equal, rows and columns both are labeled by the object names $C_{1}, C_{2}, \ldots, C_{n}$ of the universe [24]. It is a square matrix and the entries are $C_{i j}, \mathrm{i}, \mathrm{j}=1,2, \ldots, \mathrm{n}$, given by

$C_{i j}=\sum_{\mathrm{k}=1}^{\mathrm{m}}\left(f_{i k}-f_{j k}\right)$.

Here $i=1,2, \ldots, n ; j=1,2, \ldots, n ; k=1,2, \ldots, m ; n$ is number of stocks, $\mathrm{m}=$ the number of parameters. Clearly $C_{i j}=0$ for $\mathrm{i}=\mathrm{j}$.

\subsection{DRF}

Thakur [41] proposed the row sum (R) in FSS table represented by $R_{i}=\sum_{j=1}^{m} C_{i}\left[E_{j}\right]$

Here (i) and (j) are varying from 1 to number of stocks and $m$ varies from 1 to parameter.

\subsection{DMF}

Roy and Maji [24] proposed the row sum in the comparison matrix represented by the formula

$D_{i}=\sum_{i=1}^{m} C_{i j}$.

$\mathrm{m}=1,2, \ldots, \mathrm{k}$, where $\mathrm{k}$ is a parameter and (i) is varying from 1 to number of stocks. The optimal decision is represented by the value of D. 


\section{Algorithm}

A calculation for recognizable proof of an item dependent on multi input information portrayed by Return, Hazard, Profit and Liquidity is proposed. The contributions to calculation are parameter of item. The yield of proposed calculation is

1. Information the ideal number of stocks as an article.

2. Information the parameter set $\{\mathrm{E} 1, \mathrm{E} 2, \mathrm{E} 3, \mathrm{E} 4\}$ as taken by the financial specialist.

3. Build the fluffy delicate set $(F, A)$.

4. Register DRF from fluffy delicate set table and spot it in unthinkable structure. 5. Find decision value $R_{i}=\max _{\mathrm{k}} R_{K}$ form DRF table.

6. Construct the Comparison table.

7. Compute DMF from comparison table and place it in tabular form.

8. Find decision value $D_{i}=\max _{\mathrm{k}} D_{K}$ form DMF table.

Maximum value of DRF \& DMF indicated that stocks are in maximum profit while risk is less.

\section{Experimental Study}

Financial specialists need to contribute a few resources, which requires a store administrator who thinks about anticipated return and chance and picking the advantages for develop the portfolio by FSS epic strategy on premise of parameter in which expected return is greatest something else, needs to choose arbitrarily stocks making a portfolio.Portfolio chief needs to control the rebalancing cost as it especially relies on exchange cost and over the period the variety in returns will be taken fix by FSS show. At first, expect that the exchange cost is equivalent to zero.The FSS show is proposed to picked stocks for portfolio by utilizing recorded information from January 1, 2014 to December 31, 2014. The every day shutting costs of thirty stocks are picked remembering that portfolio covers broaden zones. The trade codes of the stocks are given in Table 3.

\begin{tabular}{|c|c|c|c|c|c|c|}
\hline \multirow{2}{*}{$\mathrm{F}\left(\mathrm{E}_{1}\right)=$} & $C_{1}$ & $C_{2}$ & $C_{3}$ & $C_{4}$ & $C_{5}$ & $C_{6}$ \\
\hline & .08476 & $.08358^{\prime}$ & .10403 & .12681 & $.10340^{\prime}$ & .10321 \\
\hline \multirow{16}{*}{$\mathrm{F}\left(\mathrm{E}_{2}\right)=$} & $C_{7}$ & $C_{8}$ & $C_{9}$ & $C_{10}$ & $C_{11}$ & $C_{12}$ \\
\hline & $.15541^{\prime}$ & $.07166^{3}$ &.$\overline{12181}^{\prime}$ & .09821 & $.05923^{\prime}$ & .12560 \\
\hline & $C_{13}$ & $C_{14}$ & $C_{15}$ & $C_{16}$ & $C_{17}$ & $C_{18}$ \\
\hline & $.08902^{3}$ & .12167 & .08681 & .10037 & $.09243^{3}$ & .09297 \\
\hline & $C_{19}$ & $C_{20}$ & $\mathrm{C}_{21}$ & $\mathrm{C}_{22}$ & $\mathrm{C}_{23}$ & $\mathrm{C}_{24}$ \\
\hline & $.11006^{2}$ & .12372 & $.11609^{3}$ & .08269 & $.07255^{\prime}$ & .05987 \\
\hline & $\mathrm{C}_{25}$ & $\mathrm{C}_{26}$ & $\mathrm{C}_{27}$ & $\mathrm{C}_{28}$ & $\mathrm{C}_{29}$ & $\mathrm{C}_{30}$ \\
\hline & $.07110^{3}$ & .05238 & $.02869^{3}$ & .10486 & $.23598^{\prime}$ & .10372 \\
\hline & $\mathrm{C}_{1}$ & $\mathrm{C}_{2}$ & $\mathrm{C}_{3}$ & $\mathrm{C}_{4}$ & $\mathrm{C}_{5}$ & $\mathrm{C}_{6}$ \\
\hline & .02498 & $.02597^{\prime}$ & $.00230^{\prime}$ & .03067 & .00417 & .00530 \\
\hline & $\mathrm{C}_{7}$ & $\mathrm{C}_{\mathrm{g}}$ & $\mathrm{C}_{9}$ & $\mathrm{C}_{10}$ & $\mathrm{C}_{11}$ & $\mathrm{C}_{12}$ \\
\hline & $.00685^{3}$ & .01963 & $.07245^{\prime}$ & .01284 & $.00269^{3}$ & .00000 \\
\hline & $\mathrm{C}_{13}$ & $\mathrm{C}_{14}$ & $\mathrm{C}_{15}$ & $\mathrm{C}_{16}$ & $\mathrm{C}_{17}$ & $\mathrm{C}_{18}$ \\
\hline & $.00442^{x}$ & $.00485^{3}$ & .02294 & .03765 & .01041 & .01744 \\
\hline & $\mathrm{C}_{19}$ & $\mathrm{C}_{20}$ & $\mathrm{C}_{21}$ & $\mathrm{C}_{22}$ & $\mathrm{C}_{23}$ & $\mathrm{C}_{24}$ \\
\hline & $.01644^{3}$ & $.01288^{\prime}$ & $.02589^{\prime}$ & .02597 & $.02210^{\prime}$ & .01442 \\
\hline
\end{tabular}

The normal rates of profits of the stocks are recorded in Table 4 which likewise contains profit and hazard. Table 5 gives liquidity in type of trapezoidal fluffy number $[9,17]$. In portfolio the executives, the financial specialist can secure estimations of these parameters by utilizing the Delphi Technique [26].

We speak to the technique to compute liquidity for the stock $\mathrm{C} 1$ in detail. To start with, from chronicled information the recurrence of turnover proportions is determined. The majority of the verifiable turnover proportions fall in the intervals [0.00003-0.00004], [0.00004-0.00005], [0.00005-0.00006], [0.00006-0.00007], [0.00007-0.00008]. Figure 1 presents the recurrence dispersion of verifiable turnover proportion for stock $\mathrm{C} 1$. We take the normal of the interims [0.00003-0.00004] and [0.00007-0.00008] as the left and the correct end purposes of the resilience interim, separately. In this manner, the resilience interim of the fluffy turnover proportion progress toward becoming [0.00004, 0.00008]. By watching all the recorded information, we utilize 0.00004 and 0.00008 as the base conceivable esteem and the greatest conceivable estimation of unsure turnover proportions later on, individually. In this manner, the left width is 0.00004 and the correct width is 0.00008 . The fluffy turnover rate of Stock C1, is in this way, [0.00004, $0.00008,0.00003,0.00008]$ appeared Table 5 . So also, the fluffy turnover rates of each of the 30 stocks are getting. So turnover proportion is. Table 6 demonstrates the fresh possiblistic mean estimation of the turnover rate of each stock.

Let $\mathrm{U}=\{\mathrm{C} 1, \mathrm{C} 2, \ldots \ldots, \mathrm{C} 30\}$ be the arrangement of items. The parameter $\mathrm{E}=\{$ Return, Development Rate of Net Benefit, Profit, Liquidity Proportion, Profit Proportion of Working Capital and Obligation, Settled Stocks Turnover Proportion, Obligation of stocks, Risk\}. Let A signify the subset \{Return (E1), Profit (E2), Liquidity (E3), Hazard (E4) $\}$ of the arrangement of parameter E, in which return, profit, liquidity and hazard is utilized for testingthe money related FSS display.

Here every estimation has two sections: a predicate part and a rough esteem set. A predicate name $F\left(E_{1}\right)$ is return of stocks and $\left\{\mathrm{C}_{3}, \mathrm{C}_{4}, \mathrm{C}_{5}, \mathrm{C}_{8}, \mathrm{C}_{10}, \mathrm{C}_{15}, \mathrm{C}_{19}, \mathrm{C}_{20}, \mathrm{C}_{23}, \mathrm{C}_{24}, \mathrm{C}_{27}, \mathrm{C}_{28}, \mathrm{C}_{29}, \mathrm{C}_{30}\right\}$ is an approximate value set. Consider fuzzy soft set $(\mathrm{F}, \mathrm{A})=\left\{\mathrm{F}\left(\mathrm{E}_{1}\right)\right.$, $\left.\mathrm{F}\left(\mathrm{E}_{2}\right), \mathrm{F}\left(\mathrm{E}_{3}\right), \mathrm{F}\left(\mathrm{E}_{4}\right)\right\}$, where 


\begin{tabular}{|c|c|c|c|c|c|c|}
\hline & $\mathrm{C}_{25}$ & $\mathrm{C}_{26}$ & $\mathrm{C}_{27}$ & $\mathrm{C}_{28}$ & $\mathrm{C}_{29}$ & $\mathrm{C}_{30}$ \\
\hline & $.03121^{3}$ & $.01462^{2}$ & $.02139^{2}$ &.$\overline{.01304}{ }^{3}$ & $.01198{ }^{2}$ & .02569 \\
\hline$F(E 3$ & $\mathrm{C}_{1}$ & $\mathrm{C}_{2}$ & $\mathrm{C}_{3}$ & $\mathrm{C}_{4}$ & $\mathrm{C}_{5}$ & $\mathrm{C}_{6}$ \\
\hline $\mathrm{F}(\mathrm{E}) \mathrm{I}=$ & $(.00007$ & .00002 & $.00006^{3}$ & $.00018^{2}$ & $.00021^{3}$ & .00012 \\
\hline & $\mathrm{C}_{7}$ & $\mathrm{C}_{8}$ & $\mathrm{C}_{9}$ & $\mathrm{C}_{10}$ & $\mathrm{C}_{11}$ & $\mathrm{C}_{12}$ \\
\hline & $.00019{ }^{\prime}$ & .00006 &.$\overline{00002}^{\prime}$ & .00021 & $.000044^{3}$ & .00051 \\
\hline & $\mathrm{C}_{13}$ & $\mathrm{C}_{14}$ & $\mathrm{C}_{15}$ & $\mathrm{C}_{16}$ & $\mathrm{C}_{17}$ & $\mathrm{C}_{18}$ \\
\hline & $.00043^{3}$ & .00013 & $.00007^{3}$ & $.00011^{3}$ & $.00011^{3}$ & .00007 \\
\hline & $\mathrm{C}_{19}$ & $\mathrm{C}_{20}$ & $\mathrm{C}_{21}$ & $\mathrm{C}_{22}$ & $\mathrm{C}_{23}$ & $\mathrm{C}_{24}$ \\
\hline & $.000144^{3}$ & .00035 & $.00039^{3}$ & $.00012{ }^{3}$ & .00084 & .00003 \\
\hline & $\mathrm{C}_{25}$ & $\mathrm{C}_{26}$ & $\mathrm{C}_{27}$ & $\mathrm{C}_{28}$ & $\mathrm{C}_{29}$ & $\mathrm{C}_{30}$ \\
\hline & $\overline{.00003}{ }^{3}$ & .00034 & $.00004^{3}$ & .00021 & .00027 & .00022 \\
\hline$F\left(E_{4}\right)=$ & $\mathrm{C}_{1}$ & $\mathrm{C}_{2}$ & $\mathrm{C}_{3}$ & $\mathrm{C}_{4}$ & $\mathrm{C}_{5}$ & $\mathrm{C}_{6}$ \\
\hline & .07414 & $.05816^{\prime}$ & $.06181^{2}$ & $.06685^{\prime}$ & $.06678{ }^{2}$ & $.07205^{3}$ \\
\hline & $\mathrm{C}_{7}$ & $\mathrm{C}_{8}$ & $\mathrm{C}_{9}$ & $\mathrm{C}_{10}$ & $\mathrm{C}_{11}$ & $\mathrm{C}_{12}$ \\
\hline & $.05685^{3}$ & $.06810^{\prime}$ & $.06496^{3}$ & .06514 & $.06327^{\prime}$ & $.01777^{\prime}$ \\
\hline & $\mathrm{C}_{13}$ & $\mathrm{C}_{14}$ & $\mathrm{C}_{15}$ & $\mathrm{C}_{16}$ & $\mathrm{C}_{17}$ & $\mathrm{C}_{18}$ \\
\hline & $.07983^{3}$ & .07348 & $.07242{ }^{3}$ & $.07491^{\prime}$ & $.07170^{3}$ & $.07788^{3}$ \\
\hline & $\mathrm{C}_{19}$ & $\mathrm{C}_{20}$ & $\mathrm{C}_{21}$ & $\mathrm{C}_{22}$ & $\mathrm{C}_{23}$ & $\mathrm{C}_{24}$ \\
\hline & $.02947^{2}$ &.$\overline{.00000^{2}}$ & $.05115^{\prime}$ & $.04198{ }^{3}$ & $.05502{ }^{2}$ & $.07917^{2}$ \\
\hline & $C_{25}$ & $C_{26}$ & $\mathrm{C}_{27}$ & $\mathrm{C}_{28}$ & $\mathrm{C}_{29}$ & $\mathrm{C}_{30}$ \\
\hline & $.07729^{\prime}$ & $.04078^{3}$ & $.04441^{3}$ & $.05254^{3}$ & $.02796^{3}$ & .05581 \\
\hline
\end{tabular}

Customary money related techniques have numerous basic leadership issue. Roy and Maji [24] demonstrated that the article distinguishing proof issue in which ideal choice is acknowledged dependent on most extreme score. This strategy requests development of correlation table from the resultant FSS appeared Table 7. Table 8is the consequence of the condition (10), which assumes a vital job in basic leadership.

\section{Results and Discussion}

DRF:Table 9 is the result of the equation (11) calculated by the fuzzy soft set. In decision making, DRF plays a valuable role. Maximal value of $\mathrm{R}$ represents the optimal decision. It replies that stock $\mathrm{R}_{29}$ is giving best result among companies. Optimal decision is in favour of selecting the following order.

$\mathrm{R}_{29}>\mathrm{R}_{9}>\mathrm{R}_{4}>\mathrm{R}_{7}>\mathrm{R}_{16}>\mathrm{R}_{14}>\mathrm{R}_{21}$

Result: Here maximum values are $R_{4}=0.22451, R_{7}=0.21930, R_{9}$ $=0.25923, \mathrm{R}_{14}=0.20013, \mathrm{R}_{16}=0.21304, \mathrm{R}_{21}=0.19353$ and $\mathrm{R}_{29}=$ 0.27620 of decision ranking factor in Table 9 . Here $R_{29}, R_{9}, R_{4}$, $\mathrm{R}_{7}, \mathrm{R}_{16}, \mathrm{R}_{14}, \mathrm{R}_{21}$ are the distinct value.

DMF:DMF (D) is the output of the equation (12). In Decision making, DMF plays a valuable role. In Table 9, maximum value is $\mathrm{D}_{29}=3.01454$. It is clear that stockD 29 is giving the best result among companies. Optimal decision is in favour of selecting the following order.

$$
\mathrm{D}_{29}>\mathrm{D}_{9}>\mathrm{D}_{4}>\mathrm{D}_{7}>\mathrm{D}_{16}>\mathrm{D}_{14}>\mathrm{D}_{21}
$$

Result: Maximum values are $\mathrm{D}_{4}=1.46414, \mathrm{D}_{7}=1.30784, \mathrm{D}_{9}=$ $2.50604, \mathrm{D}_{14}=0.73274, \mathrm{D}_{16}=1.12004, \mathrm{D}_{21}=0.53444$ and $\mathrm{D}_{29}=$ 3.01454 of decision making factor from Table 9. $\mathrm{D}_{29}, \mathrm{D}_{9}, \mathrm{D}_{4}, \mathrm{D}_{7}$,
$\mathrm{D}_{16}, \mathrm{D}_{14}$ and $\mathrm{D}_{21}$ are the distinct value and these values are in decreasing order.

From Table 9, $\mathrm{D}_{29}$ and $\mathrm{R}_{29}$ are maximum. Then we are considering both decision and since they are from the same stock $\mathrm{C}_{29}$ that is why $\mathrm{C}_{29}$ is the optimal stock. As same $\mathrm{C}_{9}, \mathrm{C}_{4}, \mathrm{C}_{7}, \mathrm{C}_{16}, \mathrm{C}_{14}$ and $\mathrm{C}_{21}$ could be selected as the optimal alternative. It stands to reason that $\mathrm{C}_{29}$ i.e. NBCC predicts the best stock for investors. As a result $\mathrm{C}_{9}$, $\mathrm{C}_{4}, \mathrm{C}_{7}, \mathrm{C}_{16}, \mathrm{C}_{14}$ and $\mathrm{C}_{21}$ i.e. INFRATEL, BPCL, AJANTPHARM, HEROMOTOCO, MARUTI and BANKBARODA are chosen as the ideal option as per the positioning by leader. The money related stocks from which we endeavor to build a broadened arrangement of seven stocks by FSS method.Now it is comprehended and clear that referenced positioned based methodology for portfolio enhancement gives ideal portfolio as far as return and in GSM Thakur [35] the examination between rank applicable and rankunimportant portfolio is improved for portfolio streamlining. The financial specialist's conduct understanding by the overview of [16] Gupta et al. is premise of portfolio development of seven stocks by which, speculator's portfolio expansion is in limited range 3-10 stocks.If two choice qualities are equivalent in DMF and DRF then Mean Possibility Approach (MPA) is connected by Basu et al. [3]. Thus is gotten a portfolio enhancement procedure by taking care of MOP issue (8) and (9). The ideal extents of the stock in the Table 10 are $0.34760,0.05040,0.12850,0.14710$, $0.06380,0.11380$, and 0.14880 . The outcomes acquired are fascinating and affirm the effectiveness of GA device of MATLAB for its quick combination towards the better arrangement and its processing time. The arrival is 0.10490 , profit is 0.01960 and chance is 0.09640 are the portfolio. 


\section{Conclusions}

The methodology created here for stocks allotment in portfolio utilizing FSS to consider the portfolio choice issue is novel in its sort. It is difficult for the financial specialist to choose stocks for portfolio determination as it relies on his/her inclination, expecting that the speculators make a harmony among return and hazard. Thusly as opposed to choosing the stocks arbitrarily or financial specialist's inclination, introductory positioned stock portion is performed utilizing fluffy delicate set. The primary favorable position of the proposed models is that if financial specialists are disappointed with any of the stock, new stock can be pick by the position of the stocks dependent on DRF table and DMF table.

\section{Acknowledgements}

One of the corresponding authors would like to thank Dr. GS Thakur, Assistant Professor, Department of Mathematics and Computer Applications, MANIT Bhopal (India) for his valuable guidance in the development of Soft set for solving the problems.

\section{References}

[1] Aktas, H., \&Çagman, N. (2007). Soft sets and soft groups. Information Sciences: an International Journal, 177, 2726-2735.

[2] Atanassov, K. (1986). Intuitionistic fuzzy sets. Fuzzy Sets and Systems, 64, 87-96.

[3] Basu, T.M., Mahapatra, N. K., \&Mandal, S. K. (2012). A balanced solution of a soft set based decision making problem in medical science. Applied Soft Computing, 12, 3260-3275.

[4] Bellman, R., \&Zadeh, L. A. (1970). Decision making in a fuzzy environment. Management Science, 17, 141-164.

[5] Cagman, N., \&Enginoglu, S. (2010). Soft set theory and uni-int decision making. European Journal of Operational Research, 207,848-855.

[6] Cagman, N., \&Enginoglu, S. (2010). Soft matrix theory and its decision-making. Computers and Mathematics with Applications, 59 , 3308-3314.

[7] Das, P. K., \&Borgohain, R. (2010). An application of fuzzy soft set in medical diagnosis using fuzzy arithmetic operations on fuzzy number. SIBCOLTEJO, 5, 107-116.

[8] Ehrgott, M., Klamroth, K., \&Schwehm, C. (2004). An MCDM approach to portfolio optimization. European Journal of Operational Research, 155, 752-770.

[9] Fang, Y., Lai, K. K., \& Wang, S.Y.(2006). Portfolio rebalancing model with transaction costs based on fuzzy decision theory. European Journal of Operational Research, 175, 879-893.

[10] Fang, Y., Xue, R., \& Wang, S. (2009). A Portfolio Optimization Model with Fuzzy Liquidity Constrains. International Joint Conference on Computational Sciences and Optimization. doi :10.1109/CSO.20090.362

[11] Feng, F., Jun, Y. B., Liu, X., \& Li, L.(2010). An adjustable approach to fuzzy soft set based decision making. Journal of Computational and Applied Mathematics, 234, 10- 20.

[12] Bhattacharyya, R., Hossain, S. A., \& Kar, S. (2014). Fuzzy crossentropy, mean, variance, skewness models for portfolio selection. Journal of King Saud University-Computer and Information Sciences, 26(1), 79-87.

[13] Gau, W. L., \&Buehrer, D. J. (1993). Vague sets. IEEE Transac tions on Systems, Man, and Cybernetics, 23, 610-614.

[14] Armananzas, R., \& Lozano, J. A. (2005, September). A multiobjective approach to the portfolio optimization problem. In Evolutionary Computation, 2005. The 2005 IEEE Congress on (Vol. 2, pp. 1388-1395). IEEE

[15] Faia, R., Pinto, T., \& Vale, Z. (2016). Dynamic fuzzy clustering method for decision support in electricity markets negotiation. $A D$ CAIJ: Advances in Distributed Computing and Artificial Intelligence Journal, 5(1), 23-35.

[16] Gupta, L.C., Jain, N., Choudhury, U. K., Gupta, S., Sharma, R. Kaushik, P., Chopra, M., Tyagi, M. K., \& Jain, S. (2005). Indian Household Investors survey- 2004 Society for Capital Market Research \& Development, New Delhi, India.
[17] Gupta, P., Mehlawat, M. K., \&Saxena, A. (2008). Asset portfolio optimization using fuzzy mathematical programming. Information Science, 178, 1734-1755.

[18] Herawan, T., \&Deris, M. M. (2011). A soft set approach for association rules mining. Knowledge-Based Systems, 24, 186-195.

[19] Holland, J. H. (1975). Adaption in Natural and Artificial Systems, University of Michigan: MIT Press.

[20] Jha, M., \&Srivastava, N. (20`13). Portfolio Rebalancing Model Using Fuzzy Optimization. International Journal of Scientific Engineering and Research (IJSER), 1(4), 59-70.

[21] Jun, Y. B., \& Yang, X. B.(2011). A note on the paper "Combination of interval-valued fuzzy set and soft set". Computers and Mathematics with Applications, 61, 1468-1470.

[22] Kalayathankal, S. J., \& Singh, G. S.(2010). A fuzzy soft flood alarm model. Mathematics and Computers in Simulation, 80, 887 893

[23] Kong, Z., Gao, L. Q., \& Wang, L. F. (2009). Comment on a fuzzy soft set theoretic approach to decision making problems. Journal of Computational and Applied Mathematics, 223, 540-542.

[24] Roy, A. R., \& Maji, P. K. (2007). A fuzzy soft set theoretic approach to decision making problems. Journal of Computational and Applied Mathematics, 203(2), 412-418.

[25] Laraschj, A., \&Tettamanzi, A. (1996). An evolutionary algorithm for portfolio selection within the downside risk framework. Forcasting Financial Markets, John Wiley and Sons, 275-285.

[26] Linstone, H.A., \&Turoff, M. (1975). The Delphi Method: Techniques and Applications. Massachusetts: Addison Wesley.

[27] Maji, P. K., Biswas, R., \& Roy, A. R. (2001). Fuzzy soft sets. Journal of fuzzy mathematics, 9, 589-602.

[28] Maji, P. K., Biswas, R., \& Roy, A. R. (2003). Soft set theory. Computers and Mathematics with Applications, 45, 555-562.

[29] Maji, P. K., \& Roy, A. R. (2002). An application of soft sets in a decision making problem. Computers and Mathematics with Applications, 44, 1077-1083.

[30] Markowitz, H. (1952). Portfolio selection. Journal of Finance, 7 , 77-91.

[31] Markowitz, H. (1959). Portfolio Selection: Efficient Diversification of Investments. New York: John Wiley\& Sons.

[32] Min, W. K. (2012). Similarity in soft set theory. Applied Mathematics Letters, 25, 310-314.

[33] Molodtsov, D. (1999). Soft set theory-first results. Computers and Mathematics with Application, 37, 19-31.

[34] Mushif, M. M., Sengupta, S., \& Roy, A. K., (2006). Texture classification using a novel soft set theory based classification algorithm. Proceedings of the 7th Asian conference on computer vision held in Hyderabad, India, 1, 246-254.

[35] Pawlak, Z. (1982). Rough sets. International Journal of Information and Computer Science, 11, 341-356.

[36] Rajarajeswari, P., \&Dhanalakshmi, P. (2012). Soft set theory in medical diagnosis using trapezoidal fuzzy number. International Journal of computer Application, 57, 0975-8887.

[37] Thakur, G. S. M., Bhattacharyya, R., \& Sarkar, S. (2018). Stock portfolio selection using Dempster-Shafer evidence theory. Journal of King Saud University-Computer and Information Sciences, 30(2), 223-235.

[38] Sharpe, W. F. (1964). Capital stock prices: A theory of market equilibrium under conditions of risk. The Journal of Finance, 19, $425-442$

[39] Simaan, Y. (1997). Estimation risk in portfolio selection: The mean variance model versus the mean absolute deviation model. Management Science, 43, 1437-1446.

[40] Speranza, M. G. (1993). Linear programming model for portfolio optimization. Finance, 14, 107-123

[41] Thakur, G. S. (2014). Fuzzy Soft Traffic Accident Alert Model.National Academy Science Letters, 37, 261-268.

[42] Xiao, Z., Gong, K., \&Zou, Y. (2009). A combined forecasting approach based on fuzzy soft sets. Journal of Computational and Applied Mathematics, 228, 326-333.

[43] Yang, X. B., Lin, T. Y., Yang, J.Y., Li, Y., \& Yu, D.Y. (2009). Combination of interval-valued fuzzy set and soft set. Computers and Mathematics with Applications, 58, 521-527.

[44] Yong, Y., Line, Z., Xia T., \&Hao, C. (2013). Similarity Coefficient in soft set Theory. Fuzzy Information and Engineering, 5, 119-126.

[45] Zadeh, L. A. (1965). Fuzzy sets. Information and Control, 8, 338 353 .

[46] Zadeh, L. A. (1978). (Negoita et al., 1978)Fuzzy Sets and Systems, $1,3-28$. 
[47] Zou, Y., \& Xiao, Z. (2008). Data analysis approaches of soft set under incomplete information. Knowledge-Based Systems, 21, 941-

945.

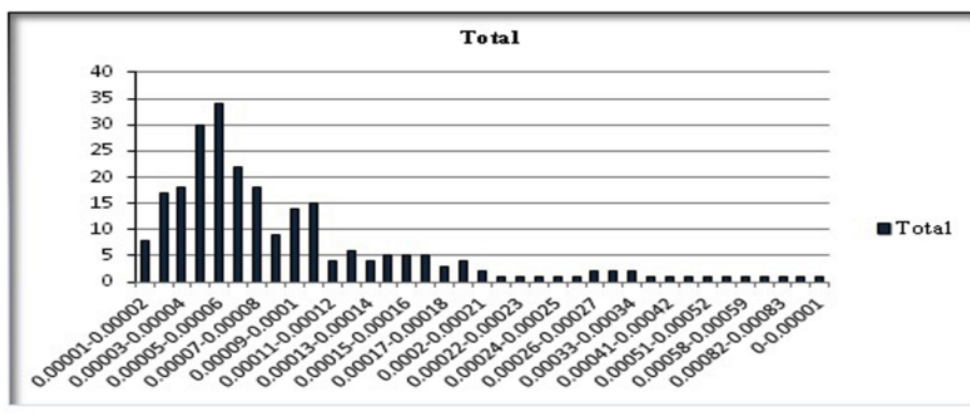

Figure 1: Frequency of turnover ratios for stock $\mathrm{C}_{1}$

Table 1: The soft set (F, A) is represent in tabular form

\begin{tabular}{|c|c|c|c|c|}
\hline S. no. & $\mathrm{e}_{1}$ & $\mathrm{e}_{2}$ & $\mathrm{e}_{3}$ & 0 \\
\hline Stock d $_{1}$ & 0 & 1 & 0 & $\mathrm{e}_{4}$ \\
\hline Stock d $_{2}$ & 1 & 0 & 1 & 0 \\
\hline Stock d $_{3}$ & 0 & 1 & 1 & 0 \\
Stock d $_{4}$ & 1 & 0 & 0 & 1 \\
\hline
\end{tabular}

Table 2: Fuzzy soft set expressed

\begin{tabular}{|c|c|c|c|}
\hline S. no. & $\mathrm{E}_{1}$ & $\mathrm{E}_{2}$ & $\mathrm{E}_{3}$ \\
\hline $\mathrm{A}_{1}$ & 0.0547 & 0.0127 & 0.0207 \\
\hline $\mathrm{A}_{2}$ & 0.1262 & 0.0000 & 0.0069 \\
\hline $\mathrm{A}_{3}$ & 0.0000 & 0.0029 & 0.0222 \\
\hline $\mathrm{A}_{4}$ & 0.1235 & 0.0151 & 0.0073 \\
\hline $\mathrm{A}_{5}$ & 0.0641 & 0.0154 & 0.0031 \\
\hline $\mathrm{A}_{6}$ & 0.0201 & 0.0145 & 0.0149 \\
\hline $\mathrm{A}_{7}$ & 0.0852 & 0.0030 & 0.0058 \\
\hline
\end{tabular}

Table 3: Stock ID of 30 Stocks

\begin{tabular}{|c|c|c|c|c|c|}
\hline Stock ID & Stock Name & Stock ID & Stock Name & Stock ID & Stock Name \\
\hline $\mathrm{C}_{1}$ & GAIL & $\mathrm{C}_{11}$ & IDEA & $\mathrm{C}_{21}$ & BANKBARODA \\
\hline $\mathrm{C}_{2}$ & ONGC & $\mathrm{C}_{12}$ & MTNL & $\mathrm{C}_{22}$ & SAIL \\
\hline $\mathrm{C}_{3}$ & IOC & $\mathrm{C}_{13}$ & TATMOTORS & $\mathrm{C}_{23}$ & TATA STEEL \\
\hline $\mathrm{C}_{4}$ & BPCL & $\mathrm{C}_{14}$ & MARUTI & $\mathrm{C}_{24}$ & WIPRO \\
\hline $\mathrm{C}_{5}$ & CIPLA & $\mathrm{C}_{15}$ & BAJAJ-AUTO & $\mathrm{C}_{25}$ & TCS \\
\hline $\mathrm{C}_{6}$ & LUPIN & $\mathrm{C}_{16}$ & HEROMOTOCO & $\mathrm{C}_{26}$ & MINDTREE \\
\hline $\mathrm{C}_{7}$ & AJANTPHARM & $\mathrm{C}_{17}$ & M\&M & $\mathrm{C}_{27}$ & INFY \\
\hline $\mathrm{C}_{8}$ & BHARTIARTL & $\mathrm{C}_{18}$ & HDFCBANK & $\mathrm{C}_{28}$ & BHEL \\
\hline $\mathrm{C}_{9}$ & INFRATEL & $\mathrm{C}_{19}$ & ICICIBANK & $\mathrm{C}_{29}$ & NBCC \\
\hline $\mathrm{C}_{10}$ & TATACOMM & $\mathrm{C}_{20}$ & SBIN & $\mathrm{C}_{30}$ & LT \\
\hline
\end{tabular}

Table 4: Return, Dividend \& Risk

\begin{tabular}{|c|c|c|c|c|c|c|c|}
\hline Stock ID & Return & Dividend & Risk & Stock ID & Return & Dividend & Risk \\
\hline $\mathrm{C}_{1}$ & 0.02476 & 0.02498 & 0.01857 & $\mathrm{C}_{16}$ & 0.04037 & 0.03765 & 0.01780 \\
\hline $\mathrm{C}_{2}$ & 0.02358 & 0.02597 & 0.03455 & $\mathrm{C}_{17}$ & 0.03243 & 0.01041 & 0.02101 \\
\hline $\mathrm{C}_{3}$ & 0.04403 & 0.00230 & 0.03090 & $\mathrm{C}_{18}$ & 0.03297 & 0.01744 & 0.01483 \\
\hline $\mathrm{C}_{4}$ & 0.06681 & 0.03067 & 0.02586 & $\mathrm{C}_{19}$ & 0.05006 & 0.01644 & 0.06324 \\
\hline $\mathrm{C}_{5}$ & 0.04340 & 0.00417 & 0.02597 & $\mathrm{C}_{20}$ & 0.06372 & 0.01288 & 0.09271 \\
\hline $\mathrm{C}_{6}$ & 0.04321 & 0.00530 & 0.02066 & $\mathrm{C}_{21}$ & 0.05609 & 0.02589 & 0.04156 \\
\hline $\mathrm{C}_{7}$ & 0.09541 & 0.00685 & 0.03586 & $\mathrm{C}_{22}$ & 0.02269 & 0.02597 & 0.05073 \\
\hline $\mathrm{C}_{8}$ & 0.01166 & 0.01963 & 0.02461 & $\mathrm{C}_{23}$ & 0.01255 & 0.02210 & 0.03769 \\
\hline $\mathrm{C}_{9}$ & 0.06181 & 0.07245 & 0.02775 & $\mathrm{C}_{24}$ & -.00013 & 0.01442 & 0.01354 \\
\hline $\mathrm{C}_{10}$ & 0.03821 & 0.01284 & 0.02757 & $\mathrm{C}_{25}$ & 0.01110 & 0.03121 & 0.01542 \\
\hline $\mathrm{C}_{11}$ & -.00077 & 0.00269 & 0.02944 & $\mathrm{C}_{26}$ & -.00762 & 0.01462 & 0.05193 \\
\hline $\mathrm{C}_{12}$ & 0.06560 & 0.00000 & 0.07494 & $\mathrm{C}_{27}$ & 0.03131 & 0.02139 & 0.04830 \\
\hline $\mathrm{C}_{13}$ & 0.02902 & 0.00442 & 0.01288 & $\mathrm{C}_{28}$ & 0.04486 & 0.01304 & 0.04017 \\
\hline $\mathrm{C}_{14}$ & 0.06167 & 0.00485 & 0.01923 & $\mathrm{C}_{29}$ & 0.17598 & 0.01198 & 0.06475 \\
\hline $\mathrm{C}_{15}$ & 0.02681 & 0.02294 & 0.02094 & $\mathrm{C}_{30}$ & 0.04372 & 0.02569 & 0.03690 \\
\hline
\end{tabular}

Table 5: Fuzzy turnover rates

\begin{tabular}{|c|c|c|c|c|}
\hline S. ID & $\tilde{\boldsymbol{L}}$ & S. ID & $\tilde{\boldsymbol{L}}$ \\
\hline $\mathrm{C}_{1}$ & 0.000040 .000080 .000030 .00008 & $\mathrm{C}_{16}$ & 0.000050 .000130 .000040 .00014 \\
\hline $\mathrm{C}_{2}$ & 0.000020 .000010 .000010 .00006 & $\mathrm{C}_{17}$ & 0.000050 .000130 .000040 .00014 \\
\hline $\mathrm{C}_{3}$ & 0.000030 .000070 .000020 .00007 & $\mathrm{C}_{18}$ & 0.000040 .000080 .000030 .00008 \\
\hline $\mathrm{C}_{4}$ & 0.000090 .000210 .000070 .00022 & $\mathrm{C}_{19}$ & 0.000080 .000160 .0000070 .00017 \\
\hline $\mathrm{C}_{5}$ & 0.000100 .000270 .000080 .00023 & $\mathrm{C}_{20}$ & 0.000240 .000400 .000220 .00042 \\
\hline $\mathrm{C}_{6}$ & 0.000060 .000140 .000050 .00015 & $\mathrm{C}_{21}$ & 0.000250 .000450 .000220 .00047 \\
\hline $\mathrm{C}_{7}$ & 0.000100 .000220 .000080 .00023 & $\mathrm{C}_{22}$ & 0.000060 .000140 .000050 .00015 \\
\hline $\mathrm{C}_{8}$ & 0.000030 .000070 .000020 .00007 & $\mathrm{C}_{23}$ & 0.000580 .000940 .000530 .00098 \\
\hline
\end{tabular}




\begin{tabular}{|l|l}
\hline $\mathrm{C}_{9}$ & \\
\hline $\mathrm{C}_{10}$ & \\
\hline $\mathrm{C}_{11}$ & \\
\hline $\mathrm{C}_{12}$ & \\
\hline $\mathrm{C}_{13}$ & \\
\hline $\mathrm{C}_{14}$ & \\
\hline $\mathrm{C}_{15}$ & \\
\hline
\end{tabular}

$\begin{array}{llll}0.00002 & 0.00001 & 0.00001 & 0.00006\end{array}$ $\begin{array}{llll}0.00012 & 0.00024 & 0.00010 & 0.00025\end{array}$ $\begin{array}{llll}0.00005 & 0.00001 & 0.00004 & 0.00009\end{array}$ $\begin{array}{llll}0.00028 & 0.00006 & 0.00024 & 0.00064\end{array}$ $\begin{array}{llll}0.00001 & 0.00074 & 0.00009 & 0.00014\end{array}$ $\begin{array}{llll}0.00007 & 0.00015 & 0.00006 & 0.00016\end{array}$ $\begin{array}{llll}0.00004 & 0.00008 & 0.00003 & 0.00008\end{array}$ $\begin{array}{llll}0.00004 & 0.00001 & 0.00003 & 0.00008\end{array}$ $\begin{array}{llll}0.00003 & 0.00001 & 0.00000 & 0.00007\end{array}$ $\begin{array}{lllll}0.00049 & 0.00008 & 0.00045 & 0.00080\end{array}$ $\begin{array}{llll}0.00005 & 0.00001 & 0.00004 & 0.00009\end{array}$ $\begin{array}{llllll}0.00012 & 0.00024 & 0.00010 & 0.00025\end{array}$ $\begin{array}{llll}0.00007 & 0.00035 & 0.00003 & 0.00038\end{array}$

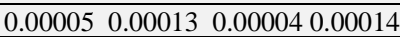

\begin{tabular}{|c|c|c|c|c|c|}
\hline Stock ID & $\tilde{\boldsymbol{L}}$ & Stock ID & $\tilde{\boldsymbol{L}}$ & Stock ID & $\tilde{\boldsymbol{L}}$ \\
\hline $\mathrm{C}_{1}$ & 0.00007 & $\mathrm{C}_{11}$ & 0.00004 & $\mathrm{C}_{21}$ & 0.00039 \\
\hline $\mathrm{C}_{2}$ & 0.00002 & $\mathrm{C}_{12}$ & 0.00051 & $\mathrm{C}_{22}$ & 0.00012 \\
\hline $\mathrm{C}_{3}$ & 0.00006 & $\mathrm{C}_{13}$ & 0.00043 & $\mathrm{C}_{23}$ & 0.00084 \\
\hline $\mathrm{C}_{4}$ & 0.00018 & $\mathrm{C}_{14}$ & 0.00013 & $\mathrm{C}_{24}$ & 0.00003 \\
\hline $\mathrm{C}_{5}$ & 0.00021 & $\mathrm{C}_{15}$ & 0.00007 & $\mathrm{C}_{25}$ & 0.00003 \\
\hline $\mathrm{C}_{6}$ & 0.00012 & $\mathrm{C}_{16}$ & 0.00011 & $\mathrm{C}_{26}$ & 0.00034 \\
\hline $\mathrm{C}_{7}$ & 0.00019 & $\mathrm{C}_{17}$ & 0.00011 & $\mathrm{C}_{27}$ & 0.00004 \\
\hline $\mathrm{C}_{8}$ & 0.00006 & $\mathrm{C}_{18}$ & 0.00007 & $\mathrm{C}_{28}$ & 0.00021 \\
\hline $\mathrm{C}_{9}$ & 0.00002 & $\mathrm{C}_{19}$ & 0.00014 & $\mathrm{C}_{29}$ & 0.00027 \\
\hline $\mathrm{C}_{10}$ & 0.00021 & $\mathrm{C}_{20}$ & 0.00035 & $\mathrm{C}_{30}$ & 0.00022 \\
\hline
\end{tabular}

Table 7: Fuzzy soft set table

\begin{tabular}{|c|c|c|c|c|}
\hline Stock ID & $\mathrm{E}_{1}$ & $\mathrm{E}_{2}$ & $\mathrm{E}_{3}$ \\
\hline $\mathrm{C}_{1}$ & 0.08476 & 0.02498 & 0.00007 \\
\hline $\mathrm{C}_{2}$ & 0.08358 & 0.02597 & 0.00002 \\
\hline $\mathrm{C}_{3}$ & 0.10403 & 0.00230 & 0.00006 \\
\hline $\mathrm{C}_{4}$ & 0.12681 & 0.03067 & 0.00018 & -0.05816 \\
\hline- & - & - & 0.06181 \\
\hline- & - & 0.01198 & - & - \\
\hline $\mathrm{C}_{29}$ & 0.23598 & 0.02569 & 0.00027 & 0.00022 \\
\hline $\mathrm{C}_{30}$ & 0.10372 & 0.02796 & \\
\hline
\end{tabular}

Table 8: Comparison Matrix for fuzzy soft set

\begin{tabular}{|c|c|c|c|c|c|c|c|}
\hline & $\mathrm{C}_{1}$ & $\mathrm{C}_{2}$ & $\mathrm{C}_{3}$ & $\mathrm{C}_{4}$ & & & $\mathrm{C}_{30}$ \\
\hline $\mathrm{C}_{1}$ & 0.00000 & 0.01622 & 0.01575 & -0.04056 & - & - & 0.02094 \\
\hline $\mathrm{C}_{2}$ & 0.01994 & 0.00000 & 0.01994 & 0.01994 & - & - & 0.01994 \\
\hline $\mathrm{C}_{3}$ & 0.03723 & 0.03723 & 0.00000 & 0.03723 & - & - & 0.03723 \\
\hline- & - & - & - & - & - & - & - \\
\hline- & - & - & & - & - & - & - \\
\hline $\mathrm{C}_{29}$ & 0.05226 & 0.05226 & 0.05226 & 0.05226 & - & - & 0.05226 \\
\hline $\mathrm{C}_{30}$ & 0.03230 & 0.03230 & 0.03231 & 0.03231 & - & - & 0.03231 \\
\hline
\end{tabular}

Table 9: Represents the value of R \& D

\begin{tabular}{|c|c|c|c|c|c|}
\hline Stock ID & DRF & DMF & Stock ID & DRF & 0.21304 \\
\hline$C_{1}$ & 0.18395 & 0.24734 & $C_{16}$ & 0.17465 \\
\hline$C_{2}$ & 0.16773 & -0.23926 & $C_{17}$ & 0.12004 \\
\hline$C_{3}$ & 0.16820 & -0.22516 & $C_{18}$ & 0.03170 \\
\hline$C_{4}$ & 0.22451 & 1.46414 & $C_{19}$ & 0.37964 \\
\hline$C_{5}$ & 0.17457 & -0.03406 & $C_{20}$ & 0.15611 \\
\hline$C_{6}$ & 0.18068 & 0.14924 & $C_{21}$ & 0.19352 \\
\hline$C_{7}$ & 0.21930 & 1.30784 & $C_{22}$ & 0.15076 \\
\hline$C_{8}$ & 0.15945 & -0.48766 & $C_{23}$ & 0.15051 \\
\hline$C_{9}$ & 0.25923 & 2.50604 & $C_{24}$ & 0.15349 \\
\hline$C_{10}$ & 0.17640 & 0.02084 & $C_{25}$ & -0.74836 \\
\hline$C_{11}$ & 0.12523 & -1.51426 & -0.75586 & 0.17963 \\
\hline$C_{12}$ & 0.14388 & -0.95476 & $C_{26}$ & 0.10812 \\
\hline$C_{14}$ & 0.17370 & -0.06016 & $C_{27}$ & 0.11774 \\
\hline$C_{15}$ & 0.20013 & 0.73274 & $C_{28}$ & -2.02756 \\
\hline
\end{tabular}

Table 10: Represents proportion of stocks

\begin{tabular}{|c|c|c|c|c|c|}
\hline Stock ID & Proportion & Stock ID & Proportion & Stock ID & Proportion \\
\hline $\mathrm{C}_{1}$ & 0 & $\mathrm{C}_{11}$ & 0 & $\mathrm{C}_{21}$ & 0.14880 \\
\hline $\mathrm{C}_{2}$ & 0 & $\mathrm{C}_{12}$ & 0 & $\mathrm{C}_{22}$ & 0 \\
\hline $\mathrm{C}_{3}$ & 0 & $\mathrm{C}_{13}$ & 0 & $\mathrm{C}_{23}$ & 0 \\
\hline $\mathrm{C}_{4}$ & 0.12850 & $\mathrm{C}_{14}$ & 0.11380 & $\mathrm{C}_{24}$ & 0 \\
\hline $\mathrm{C}_{5}$ & 0 & $\mathrm{C}_{15}$ & 0 & $\mathrm{C}_{25}$ & 0 \\
\hline $\mathrm{C}_{6}$ & 0 & $\mathrm{C}_{16}$ & 0.06380 & $\mathrm{C}_{26}$ & 0 \\
\hline $\mathrm{C}_{7}$ & 0.14710 & $\mathrm{C}_{17}$ & 0 & $\mathrm{C}_{27}$ & 0 \\
\hline $\mathrm{C}_{8}$ & 0 & $\mathrm{C}_{18}$ & 0 & $\mathrm{C}_{28}$ & 0 \\
\hline $\mathrm{C}_{9}$ & 0.05040 & $\mathrm{C}_{19}$ & 0 & $\mathrm{C}_{29}$ & 0.34760 \\
\hline $\mathrm{C}_{10}$ & 0 & $\mathrm{C}_{20}$ & 0 & $\mathrm{C}_{30}$ & 0 \\
\hline
\end{tabular}

